\section{Human hemoglobin G-Makassar variant masquerading as sickle cell anemia}

\author{
Ahmad Sabry Mohamad, ${ }^{1}$ \\ Roszymah Hamzah, ${ }^{2}$ \\ Veena Selvaratnam, ${ }^{2}$ \\ Subramanian Yegapan, ${ }^{2}$ \\ Jameela Sathar ${ }^{2}$ \\ ${ }^{1}$ Universiti Kuala Lumpur - British \\ Malaysian Institute, Gombak, Selangor; \\ ${ }^{2}$ Hematology Department, Ampang \\ Hospital, Ampang, Selangor, Malaysia
}

\begin{abstract}
Human hemoglobin of G-Makassar variant has been reported very rarely with Beta Thalassemia. In year 1969 Hb GMakassar was first identified in Makassar, Sulawesi (Celebes), Republic of Indonesia. The disease was first published in 1969 and 33 years later it has been reported at a family of Thailand origin. We report a 45-yearold Malay man who was investigated for anemia and thrombocytopenia then diagnosed with $\mathrm{Hb}$ G-Makassar. This finding describes as a new Hemoglobin GMakassar discovered in Malaysia after 14 years diagnosed in Thailand.
\end{abstract}

\section{Introduction}

Hemoglobin $(\mathrm{Hb})$ G-Makassar mutation was first identified in Indonesia, which are bound Malaysia and the Southeast Asia. Blackwell et al. were described the patient was living and origin of Thailand. ${ }^{1}$ The $\mathrm{Hb}$ G-Makassar electrophoretic mobility slower-moving $\beta$ hemoglobin variant exhibited to have its anatomical abnormality at the $\beta$ 6 or A3 location where the glutamyl residue typically is replaced by an alanyl residue., 2,3 Meanwhile the substitution of single amino acid in the gene encoding $\beta$-globin subunit $\beta-6$ glutamyl to valine will result as sickle cell disease. ${ }^{4}$ Both routine hemoglobin electrophoresis separation by cation-exchange High Performance Liquid Chromatography (HPLC) and cellulose acetate electrophoresis were unable to separate $\mathrm{Hb}$ G-Makassar and $\mathrm{Hb} \mathrm{S}$ where they were found to share the same identical properties. As a result, $\mathrm{Hb}$ G-Makassar and $\mathrm{Hb} \mathrm{S}$ could be incorrectly identified for each other and therefore can be misdiagnosed as Sickle Cell Disease $(\mathrm{SCD}) .{ }^{5}$

\section{Case Report}

A 45-year-old man was previously investigated at Malaysian private hospital for anemia and thrombocytopenia for a year. His platelet was normalized while anemia remained. He then presented to Malaysian government hospital of Haematology Centre with symptomatic anemia and bleeding haemorrhoids. He had frequent bleeding haemorrhoids in the past that required intermittent blood transfusions management. He has no hepatplenomegaly.

Counts on presentation at our centre was; $\mathrm{Hb}: 5.7 \mathrm{~g} / \mathrm{dL}, \mathrm{MCV}$ : $68.9 \mathrm{fL} \mathrm{MCH}$ : $20.2 \mathrm{pg}$ MCHC: $29.3 \mathrm{~g} / \mathrm{dL}$, platelet: 407 and WBC: $8.5 \times 10^{3} / \mu \mathrm{L}$. The initial iron (Ferum) was $2.4 \mu \mathrm{mol} / \mathrm{L}$ and ferritin was $5.5 \mu \mathrm{g} / \mathrm{L}$ before started iron therapy. Both iron and ferritin level were improved after iron therapy. The latest ferritin level was $53.4 \mu \mathrm{g} / \mathrm{L}$ in 2017.

Peripheral blood film showed thalassemia pictures but did not reveal any sickle cells. $\mathrm{Hb}$ analysis was initially suggestive of compound heterozygous state of $\mathrm{Hb} \mathrm{S} / \mathrm{E}$. However, $\beta$ DNA analysis revealed compound Heterozygous codon 26 [GAG>AAG] $\mathrm{HbE}\left(\beta^{\mathrm{E}}\right)$ and codon 6 (GAG->GCG) Hb G-Makassar mutations while $\alpha$ DNA analysis showed negative result of mutations. Apart of haemorrhoids, the patient is otherwise asymptomatic. After he had surgery for haemorrhoids, his $\mathrm{Hb}$ was stable ranging from $9 \mathrm{~g} / \mathrm{dL}$ to $12 \mathrm{~g} / \mathrm{dL}$, MCH $19 \mathrm{pg}$ to $25 \mathrm{pg}$, MCV $63 \mathrm{fL}$ to $74 \mathrm{fL}$. He was transfusion independent and only treated with iron therapies. He also does not need regular follow up. During follow up, he never has jaundice. His total bilirubin was $8 \mu \mathrm{mol} / \mathrm{L}$ and did not raised. The reticulocyte percentage was normal but the absolute reticulocyte count was low with $0.67 \%$ and $0.029 \times 10^{6} / \mu \mathrm{L}$ respectively.

\section{Results}

Figure 1 reveals that the morphology of red blood cell on peripheral blood smear of this patient was microcytic hypochromic anemia with presence of occasional target cells (stain was purchased from Sysmex Malaysia Sdn. Bhd.). This finding could be related to heterozygous $\beta$ variant ( $\mathrm{Hb} \mathrm{E}$ ) detected in this patient as in $\mathrm{Hb}$ GMakassar, it was reported as normal morphology. The typical feature of sickle cell anemia such as boat-shaped cell or sickle cell was not seen.

Figure 2 demonstrates that $\mathrm{Hb}$ Makassar variant moved to the same location as $\mathrm{Hb} \mathrm{S}$, which was detected at zone
Correspondence: Ahmad Sabry Mohamad, Medical Engineering Section, Universiti Kuala Lumpur - British Malaysian Institute, 53100 Gombak, Selangor, Malaysia.

Tel.: +6012.949.7800.

E-mail: sabry@unikl.edu.my

Key words: Hemoglobin G-Makassar; electrophoresis; beta thalassemia; DNA analysis; sickle cell disease.

Acknowledgments: the authors would to thanks to all Haematology Clinical Referral Laboratory staff for their technical assistance. We extend our special thanks to all staff of Molecular Genetics Laboratory, Haematology Unit, Institute of Medical Research, Kuala Lumpur Hospital for their help to complete this report.

Received for publication: 4 May 2018.

Revision received: 11 July 2018.

Accepted for publication: 31 July 2018.

This work is licensed under a Creative Commons Attribution-NonCommercial 4.0 International License (CC BY-NC 4.0).

CCopyright .A.S. Mohamad et al., 2018

Licensee PAGEPress, Italy

Hematology Reports 2018; 10:7210

doi:10.4081/hr.2018.7210

five (Z5) from the routine hemoglobin capillary electrophoresis. Moreover, the other $\beta$ hemoglobin variants on the same $\mathrm{Z} 5$ are $\mathrm{Hb}$ Dhofar, Hb S-Antilles, Hb Hamadan, while $\alpha$ hemoglobin variants on the same Z5 are $\mathrm{Hb}$ Arya, $\mathrm{Hb}$ Hasharon, Hb Handsworth, $\mathrm{Hb}$ Ottawa, $\mathrm{Hb}$ Fort de France, $\mathrm{Hb}$ Montgomery, Lombard-Hb A2 variant, Cemenelum-Hb A2 variant and Jackson-Hb A2 variant. Denatured $\mathrm{Hb} \mathrm{O}-\mathrm{Arab}$ also observed at the $\mathrm{Z} 5$ peak. ${ }^{5}$

In this particular case, $\mathrm{Hb} \mathrm{S}$ fraction was $63 \%$ with the presence of $\mathrm{Hb}$ E $25.7 \%$, while minimal $\mathrm{Hb} \mathrm{A}$ and $\mathrm{Hb} \mathrm{F}$ was identified. $\mathrm{Hb}$ A2 was minimally elevated. This can be mistakenly identified as Compound Heterozygus state of $\mathrm{Hb} \mathrm{S} / \mathrm{E}$ thalassemia.

Figure 3 demonstrates that the mobility of the hemoglobin variant $\mathrm{Hb}$ G-Makassar in cellulose acetate electrophoresis was identical to $\mathrm{Hb} \mathrm{S}$. Therefore, the effect of alkaline $\mathrm{pH}$ was not accomplished to separating $\mathrm{Hb} \mathrm{S}, \mathrm{Hb}$ Punjab and $\mathrm{Hb}$ Tak through cellulose acetate hemoglobin electrophoresis. Hence, they appear to migrate to the same position as the $\mathrm{Hb}$ F. Hb G-Makassar also retained at the same location as $\mathrm{Hb} \mathrm{S}$ at acidic $\mathrm{pH}$ on cellulose acetate hemoglobin electrophoresis. Because of this similarity, the differential diagnosis of the variants are periodically problematic. ${ }^{6-8}$ 
Figure 4 describes a DNA sequence on $\beta$ DNA analysis using PCR amplification that confirmed $\mathrm{Hb}$ G-Makassar mutation (GAG -> GCG). DNA molecular analysis of the $\beta$-globin genes identified the GAG -> GCG mutation in codon 6 where the mutation bound for Hb G-Makassar [ $\beta 6(\mathrm{~A} 3) \mathrm{Glu}$ -> Ala]. In addition, he also had a single point mutation in the codon 26 causing $\beta^{\mathrm{E}}$ thalassemia, [GAG -> AAG]; he is aggregate heterozygote for $\mathrm{Hb}$ G-Makassar/ $\beta^{\mathrm{E}}$ thalassemia. The $\mathrm{Hb}$ G-Makassar mutation was first diagnosed using Polymerase Chain Reaction-Restriction Fragment Length Polymorphism (PCR-RFLP) technique. It was detected by Acil restriction site in the $886 \mathrm{bp}$ fragment, and this fragment was further absorbed on 645 and 241 bp fragments, correspondingly in the $\mathrm{Hb}$ G-Makassar allele, variant of the second nucleotide of the codon $6, \mathrm{~A}->\mathrm{C}$.

\section{Discussion}

Hemoglobinopathies are inherited abnormalities of globin chain synthesis and Sickle cell anemia is the commonest monogenic diseases as described by Thom et al. ${ }^{9}$ Piel and David recently reported more than 1000 natural mutation in the human hemoglobin variants. These hemoglobin variants were found to be the effect of single amino acid substitutions throughout the gene molecule. The clinical effects of the hemoglobin variants are vary ranging from clinically insignificant to severe forms of hemoglobin disorder. ${ }^{10}$ Nevertheless, over 300,000 babies are estimated to be delivered every year with one of these abnormalities. ${ }^{11}$ Sickle-cell disease is most commonly found in sub-Saharan Africa, and parts of the Mediterranean region, the Middle East and the Indian subcontinent. Meanwhile Betathalassemia is most common among populations of Mediterranean, African and South Asian ancestry. The prevalence for Southeast Asia is $0-11 \%$ of population. However, the incidence of $\mathrm{Hb}$ G-Makassar remains less informative as reported by Weatherall and Piel. ${ }^{12-14}$

Many variants of the $\beta$ - and $\alpha$-globin chain will migrate like $\mathrm{Hb} \mathrm{S}$ under the conditions of alkaline electrophoresis though some variants such $\mathrm{Hb} \mathrm{D}$ or $\mathrm{Hb} \mathrm{G}$ can be separated by acid electrophoresis but not Hb G-Makassar. Hb G-Makassar cannot be distinguished from $\mathrm{Hb} \mathrm{S}$ by isoelectric focusing, HPLC, globin chain electrophoresis or hemoglobin electrophoresis. ${ }^{15}$ Table 1 shows the identification of $\mathrm{Hb}$ G-Makassar in this case was obtained by $\beta$ DNA sequence analysis, which revealed a single nucleotide substitution $\mathrm{GAG}^{->} \mathrm{GCG}$ of $\beta$ -

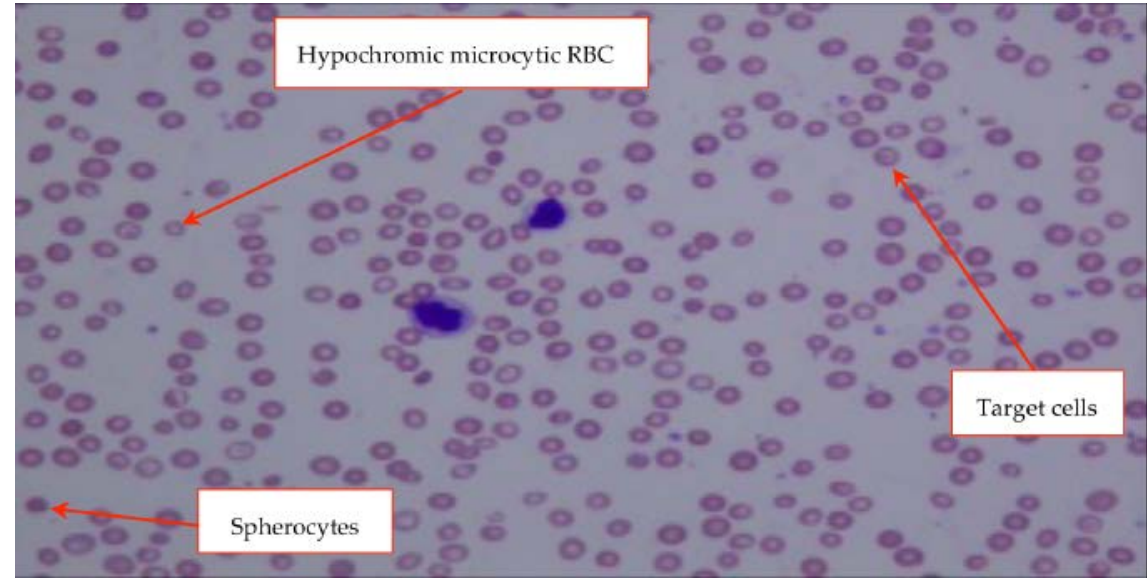

Figure 1. Peripheral blood smears film using May-Grünwald-Giemsa staining shows negative sickle cell of $\mathrm{Hb}$ G-Makassar.

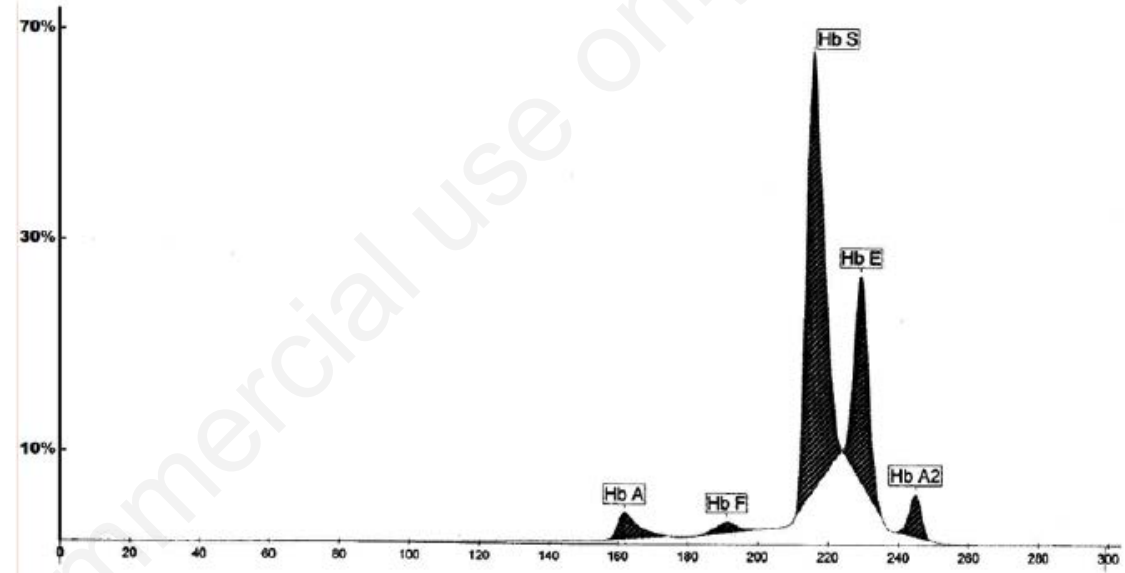

Figure 2. Hemoglobin capillary electrophoresis analysis showing presence of $\mathbf{H b}$ GMakassar which has properties identical to those $\mathrm{Hb} \mathrm{S}$. Where $\mathrm{Hb} \mathrm{A}=4.6 \%, \mathrm{Hb} \mathrm{F}=$ $2.1 \%, \mathrm{Hb} \mathrm{S}=63.0 \%, \mathrm{Hb} \mathrm{E}=25.7 \%, \mathrm{Hb} \mathrm{A} 2=4.6 \%$.
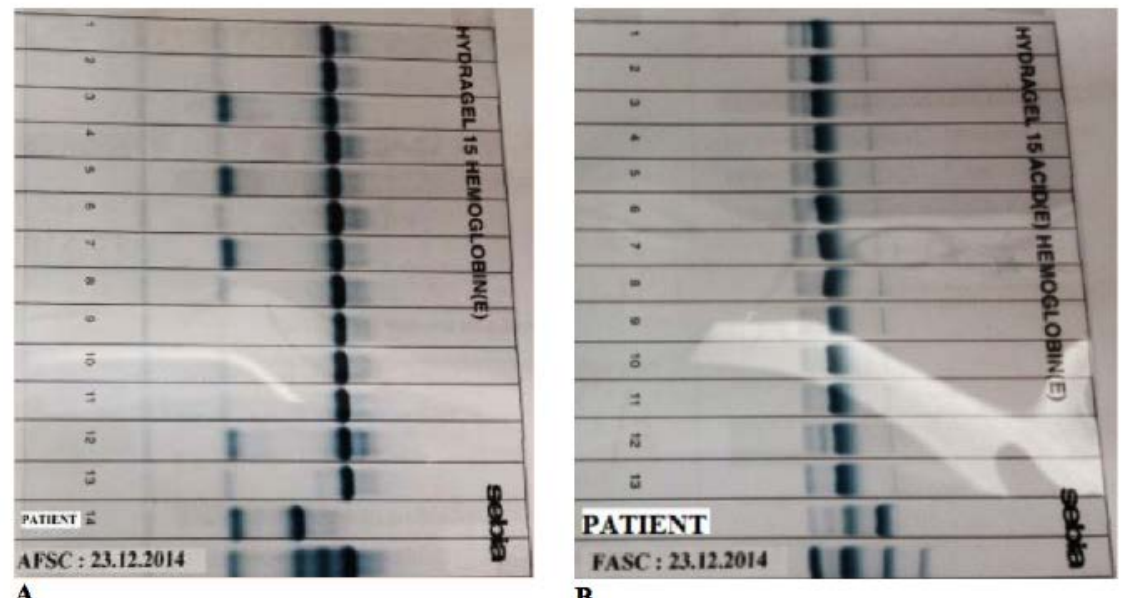

Figure 3. Cellulose acetate hemoglobin electrophoresis at (A) alkaline $\mathrm{pH}(\mathrm{B})$ acid $\mathrm{pH}$ show presence of $\mathrm{Hb} \mathrm{S}$. 
globin gene at codon $6[\beta$ 6:Glu->Ala $]$ and Heterozygous codon 26 [GAG $>$ AAG] $\mathrm{HbE}$ $\left(\beta^{\mathrm{E}}\right)$. As there was no sickle cell noted on peripheral blood film, sickling test can be performed to identify the presence of $\mathrm{Hb}$ S. ${ }^{16,17}$

Hemoglobin electrophoresis of this patient showed predominantly $\mathrm{Hb}$ GMakassar (63.0\%), presence of $\mathrm{Hb} \mathrm{E}$ (25.7\%), minimal $\mathrm{Hb} \mathrm{A}(4.6 \%)$ and $\mathrm{Hb} \mathrm{F}$ (2.1\%). After reviewed his DNA analysis, he was diagnosed as compound heterozygote $\mathrm{Hb} \mathrm{G}-\mathrm{Makassar} / \beta \mathrm{E}-$ thalassemia. The clinical expression of this was a $\beta$-thalassemia minor phenotype. In correlation to his clinical features, he has no splenomegaly and no signs of hemolysis. Hence, the presence of $\mathrm{Hb}$ G-Makassar was appeared to be functionally proportionate to $\mathrm{Hb} \mathrm{A}$. The level of $\mathrm{Hb} \mathrm{A} 2$ in $\mathrm{Hb}$ G-
Makassar trait (ranging from 3.7\% to $4.7 \%$ ) and compound heterozygosity with $\beta^{\mathrm{O}}$-thalasemia $(9.1 \%)$ were noted to be higher than typically present in normal controls (ranging from $2.3 \%$ to $3.2 \%$ ) and $\beta^{\mathrm{O}}$-thalassemia traits (ranging from $4.0 \%$ to $6.0 \%$ ). This is similar to $\mathrm{Hb} \mathrm{S}$ trait and $\mathrm{Hb} \mathrm{S} / \beta$-thalassemia. Increased of $\mathrm{Hb} \mathrm{A} 2$ might reflect of an elevation of $\alpha$-globin chains available for tetramer formation with $\delta$-globin chains, indicating a minimally reduced affinity of the $\beta S$ with the $\alpha$ chain. An analogous explanation may employ to $\mathrm{Hb}$ G-Makassar variant.

Position of the structural change of $\mathrm{Hb}$ G-Makassar occurs at the same as in $\mathrm{Hb} \mathrm{S}$, however their clinical manifestations are absolutely different. Homozygous expression of $\mathrm{Hb} \mathrm{S}$ concludes sickle cell disease, which is a vaso-occlusive condition and chronic hemolytic anemia that can sometimes be fatal. ${ }^{15} \mathrm{Hb}$ G-Makassar heterozygotes are haematologically normal and clinically asymptomatic but $\mathrm{Hb}$ GMakassar $/ \beta^{0}$-thalassemia compound heterozygote has attribute to thalassemia minor. On the other hand, homozygous $\mathrm{Hb}$ G-Makassar is almost normal and did not have any abnormal clinical feature. Nevertheless, the $\mathrm{Hb}$ G-Makassar was viewed and become less informative on their clinical phenotype and haematological disorder. The difference in clinical manifestations of these two hemoglobin variants might be due to the alteration of the Glu $\rightarrow$ Ala side chain which is not produced enough for polymerization and generation of red cell sickling.

Table 1. DNA analysis of $\beta$-globin gene/cluster and test methods conducted at Institute for Medical Research (Malaysia) Laboratory.

Method 1: Multiplex application refractory
mutation system (ARMS) of polymerase chain
reaction (PCR)

$-88[\mathrm{C}>\mathrm{T}]\left(\beta^{+}\right),-29[\mathrm{~A}>\mathrm{G}]\left(\beta^{+}\right),-29[\mathrm{~A}>\mathrm{G}]\left(\beta^{+}\right), \mathrm{cap}+1[\mathrm{~A}>\mathrm{G}]\left(\beta^{+}\right)$, initiation codon $[\mathrm{A} T \mathrm{G}>\mathrm{AGG}]\left(\beta^{\circ}\right)$, codon $6[\mathrm{G} A \mathrm{G}>\mathrm{GTG}] \mathrm{Hb} \mathrm{S}\left(\beta^{\mathrm{s}}\right)$, codon $17[\mathrm{~A} A \mathrm{G}>\mathrm{T} A \mathrm{G}]\left(\beta^{\circ}\right)$, codon $19[\mathrm{~A} A \mathrm{C}>\mathrm{A} G \mathrm{C}]$ Malay $\left(\beta^{+}\right)$, codon $26[\mathrm{G} A \mathrm{G}>\mathrm{A} A \mathrm{G}] \mathrm{Hb} \mathrm{E}\left(\beta^{\mathrm{E}}\right), \operatorname{IVS} 1-1[\mathrm{G}>\mathrm{T}]\left(\beta^{\circ}\right), \operatorname{IVS} 1-1[\mathrm{G}>\mathrm{A}]\left(\beta^{\circ}\right)$, IVS $1-5[\mathrm{G}>\mathrm{C}]\left(\beta^{\circ}\right)$, codon 41/42 [-TTCT] $\left(\beta^{\circ}\right)$, codon $43[\mathrm{G} A \mathrm{G}>\mathrm{T} A \mathrm{G}]$ $\left(\beta^{\circ}\right)$, codon 71/72 [+A] $\left(\beta^{\circ}\right)$, IVS 2-654 [C>T] $\left(\beta^{\circ}\right)$, Poly A[AATA $A A>$ AATA $G$ A $]\left(\beta^{+}\right)$
B-Thalassemia from -100 of the $5^{6}$ untranslated region to $+3203^{6}$ unstranlated region to +320 of the $3^{\text {c }}$ untranlated region

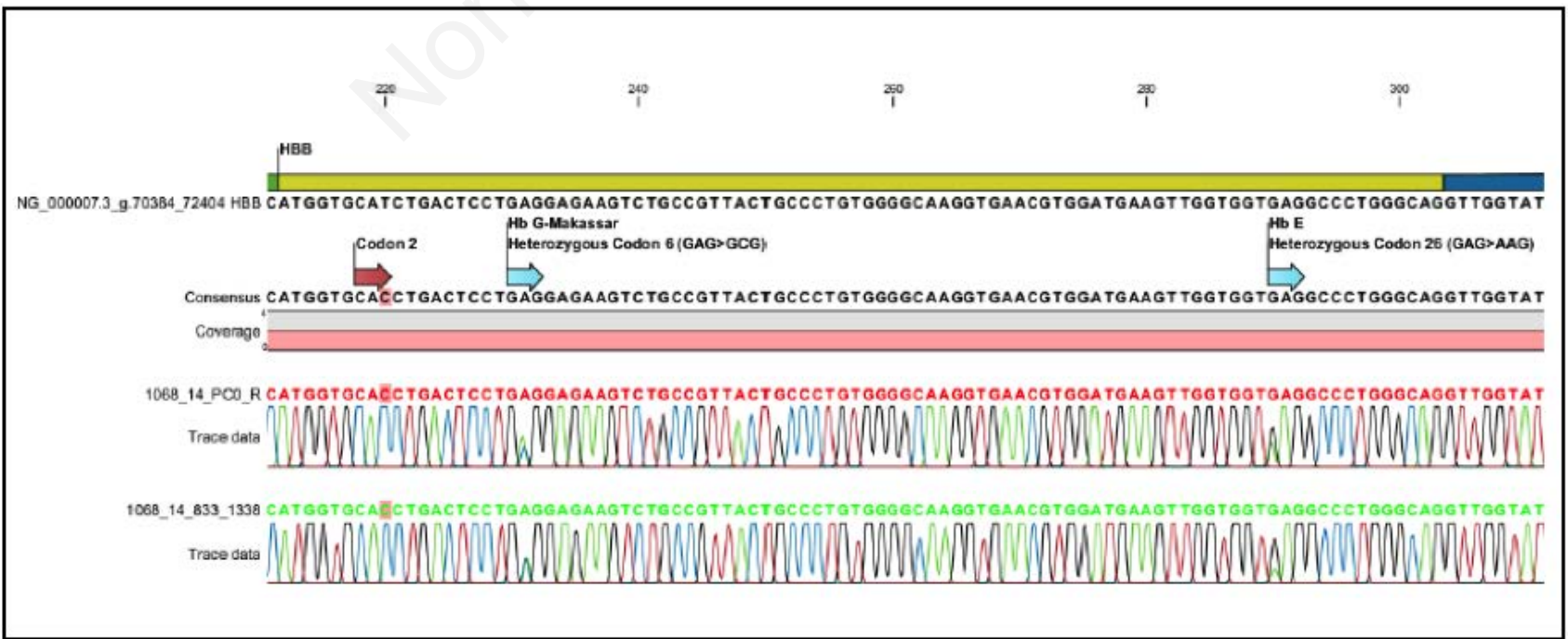

Figure 4. Direct genomic sequencing results of $\beta$ DNA analysis showing the Compound heterozygous codon 6 (GAG -> GCG) Hb GMakassar and codon 26 [GAG $\rightarrow$ AAG] Hb E $(\beta E)$ mutations. 


\section{Conclusions}

There are high possibilities of $\mathrm{Hb} \mathrm{S}$ and $\mathrm{Hb}$ G-Makassar presences in ethnic group such multiracial groups as a result of population migration. As $\mathrm{Hb}$ G-Makassar cannot be differentiated from $\mathrm{Hb} \mathrm{S}$ on both acid and alkaline electrophoresis, DNA analysis would be the definitive for the diagnosis of $\mathrm{Hb}$ G-Makassar.

\section{References}

1. Blackwell RQ. Hemoglobin G Makassar: $\beta 6$ Glu $\rightarrow$ Ala. (BBA)Protein Structure 214.3 Biochim Biophys Acta 1970:396-401.

2. HbVar: A database of Human Hemoglobin Variants and Thalassemias. Available from: http://globin.bx.psu.edu/hbvar/menu.ht ml Accessed: November 13, 2016.

3. Viprakasit V. Hb G-Makassar $[\beta 6$ (A3) $\mathrm{Glu} \rightarrow \mathrm{Ala} ; \mathrm{CODON} 6(\mathrm{GAG} \rightarrow \mathrm{GCG})]:$ molecular characterization, clinical, and hematological effects. Hemoglobin 2002;26:245-53.

4. Weatherall DJ. The inherited diseases of hemoglobin are an emerging global health burden. Blood 2010;115:4331-6.

5. Sangkitporn S. Hb G Makassar (Beta 6: $\mathrm{Glu} \rightarrow$ Ala) in a Thai Family. J Med Assoc Thailand 2002;85:577-82.

6. Old J. Haemoglobin pattern analysis; 2012.

7. Sanchaisuriya K. Multiplex allele-specific PCR assay for differential diagnosis of $\mathrm{Hb} \mathrm{S}, \mathrm{Hb}$ D-Punjab and $\mathrm{Hb}$ Tak. Clin Chim Acta 2004;343:129-34.

8. Steinberg MH. Disorders of hemoglobin. Disord Hemoglob 2001 [Epub ahead of print].

9. Thom CS. Hemoglobin variants: biochemical properties and clinical correlates. Cold Spring Harbor Perspect Med 2013;3:a011858.

10. Piel FB, Weatherall DJ. Sickle-cell disease: a call to action. Trans R Soc Trop Med Hyg 2015;109:355-6.

11. Forget BG, Bunn HF. Classification of the disorders of hemoglobin. Cold Spring Harbor Perspect Med 2013;3:a011684.

12. Akinbami AO. Hereditary persistence of fetal hemoglobin caused by single nucleotide promoter mutations in sickle cell trait and $\mathrm{Hb} \mathrm{SC}$ disease. Hemoglobin 2016;40:64-5.

13. Piel FB. The present and future global burden of the inherited disorders of hemoglobin. Hematol Oncol Clin N Am 2016;30:327-41.

14. Okpala I, ed. Practical management of haemoglobinopathies. New York: John Wiley \& Sons; 2008.

15. Figueiredo MS. The compound state: $\mathrm{Hb} \mathrm{S} /$ beta-thalassemia. Rev Brasil Hematol Hemoter 2015;37:150-2.

16. Steinberg MH. Disorders of hemoglobin: genetics, pathophysiology, and clinical management. Cambridge: Cambridge University Press; 2009.

17. Khor SF. The haemoglobin G Makassar (Codon 6 GAG $>$ GCG) cases in Malaysia: molecular identification and characterization. J Biomed Clin Sci 2018;2:52-3 